DOI: 10.1515/pof-2016-0009

VOLUME 8, ISSUE 2, 2016

ISSN: 2036-5438

\title{
Reforming the financing of the EU budget: Outlook \\ by
}

Alessandro D'Alfonso*

Perspectives on Federalism, Vol. 8, issue 2, 2016 


\begin{abstract}
This paper provides a general overview of the EU's own resources system, and of the debate on its possible reform within the current legal framework. Two alternative reforms are discussed, along with their possible advantages and drawbacks: 1) a simplified system based only on a resource related to gross national income; and 2) the introduction of new genuine own resources and the possible elimination of some current own resources. The second option, which has long been called for by the European Parliament, is explored in further detail, with an overview of the potential candidates for new own resources analysed by the European Commission prior to its 2011 reform proposal. The current outlook for a possible reform focuses on the ongoing work of the high-level group on own resources chaired by Professor Mario Monti, presenting the main obstacles to change and possible ways forward. This paper updates the author's in-depth analysis How the EU budget is financed: The "own resources" system and the debate on its reform (European Parliamentary Research Service, Brussels).
\end{abstract}

Key-words

European Union, own resources system, reform proposals 


\section{Introduction}

The EU's annual budget is worth around 1\% of its Member States' gross national income (GNI), or $2 \%$ of total public spending in the EU. It ignites heated debate on both its nature and objectives. Recent crises have triggered criticism that the current EU budget is unfit to tackle the challenges with which the EU is confronted. The revenue side of the budget is equally controversial, and also the subject of debate. Different options for financing $\mathrm{EU}$ policies reflect different visions of the $\mathrm{EU}$, ranging from the intergovernmental to a more integrated approach.

Contributions from national budgets are the usual means of financing international organisations, such as the United Nations, in which citizens are only indirectly represented through their governments. In the EU, citizens are represented both directly in the European Parliament (EP) and indirectly by their governments in the Council. In many respects, the EU institutional structure is unique, being neither an inter-governmental organisation nor a federal State.

This originality is also seen in the financing of the EU budget. With a view to ensuring the financial autonomy of the Union, Article 311 of the Treaty on the Functioning of the European Union (TFEU) states that "own resources" finance its budget. The Council decides the rules governing the own resources system through a special legislative procedure, which requires unanimity and ratification by all Member States, while the EP is only consulted.

In the absence of a definition of own resources, academia has long debated their nature. Over time, their automaticity has been recognised as one of their main characteristics. This means that, once the system has been ratified, own resources are automatically due to the EU without the need for a further decision at Member State level. The Court of Justice of the EU (ECJ) has confirmed this crucial aspect, through its ruling that delays by Member States in making available own resources are unlawful. ${ }^{\mathrm{I}}$

The need for unanimity explains the difficult evolution the own resources system has experienced. That has not prevented agreements from being reached, with six Decisions having been adopted after the first one in 1970. However, many analysts deem the 
requirement for unanimity to have resulted in a system that is more opaque than it otherwise would be. Modifications have often added new layers of complexity onto the existing mechanism rather than streamlining it.

\section{The current system}

\subsection{Main data}

The Council Decision (EC, EURATOM) 2007/436 is the legal basis currently in force, pending ratification of the new Decision, ${ }^{\text {II }}$ which will apply retroactively from 1 January 2014. The maximum level of resources that the EU may raise during one year, its own resources ceiling, is set at $1.23 \%$ of the Union's GNI. The total revenue, which is always below the own resources ceiling, was $€ 143.9$ billion in 2014.

The financing of the EU budget comes from three categories of own resources:

- Traditional own resources (TOR), mainly customs duties, represented $11.5 \%$ of total revenue in 2014. Member States retain 25\% of the amounts to cover collection costs.

- VAT resource accounted for $12.3 \%$ of total revenue in 2014. Based on a very complex statistical calculation to harmonise Member States' VAT bases, its link to actual VAT proceeds collected in Member States is very weak. With different consumption patterns across the EU, VAT bases are capped at $50 \%$ of GNI to counter potentially regressive aspects of the resource. For 2007-13, the standard call rate of this resource $(0.30 \%)$ was lowered for Austria, Germany, Sweden and the Netherlands.

- GNI resource now represents by far the most significant source of revenue (around $69 \%$ of the total in 2014), despite being introduced as the "budget balancing element".

Other revenue, which is not classified as own resources, includes taxes on EU staff salaries, contributions from non-EU countries to certain programmes, and fines on companies for breaching competition law. In 2014, other revenue of $€ 8.6$ billion accounted for $6.9 \%$ of the total. 
The UK rebate means that its contribution is lowered by a reimbursement. The UK government argues that the reasons for this arrangement, introduced in 1985 (and subsequently modified on a number of occasions), remain valid. Based on a complex statistical calculation, it changes every year (see table 1). It was worth almost $€ 6.1$ billion in 2014, reducing the UK contribution by around 35\% to €11.3 billion. Three Member States (France, Italy and Spain) funded 58\% of the UK rebate. Austria, Germany, Sweden and the Netherlands benefit from a permanent reduction in their contributions to the financing of the UK rebate, paying one-quarter of their calculated share. The same four countries also enjoyed one or more temporary correction mechanisms for 2007-13. The estimated effect of these adjustments on the draft budget for 2012 ranged from $€ 95$ million for Austria to $€ 1.6$ billion for Germany. For 2007-13, several countries obtained exceptions for the expenditure side of the budget, ${ }^{\mathrm{III}}$ such as resources earmarked for projects, regions or Member States. Despite appearing less significant in size, these additional corrections for expenditure contributed to the overall opacity of the system. IV

Table 1 - UK national contribution and rebate (in million euros)

\begin{tabular}{|l|c|c|r|r|r|r|}
\hline & 2009 & 2010 & \multicolumn{1}{|c|}{2011} & \multicolumn{1}{c|}{2012} & \multicolumn{1}{c|}{2013} & \multicolumn{1}{c|}{2014} \\
\hline $\begin{array}{l}\text { Gross National Contribution } \\
\text { (GNC) }\end{array}$ & 12922 & 15627 & 14780 & 17186 & 18757 & 17458 \\
\hline UK rebate & 5658 & 3563 & 3596 & 3804 & 4330 & 6066 \\
\hline Final National Contribution & 7880 & 12146 & 11273 & 13461 & 14510 & 11342 \\
\hline UK rebate as \% of GNC & $44 \%$ & $23 \%$ & $24 \%$ & $22 \%$ & $23 \%$ & $35 \%$ \\
\hline
\end{tabular}

Data source: Elaboration on European Commission data.

\subsection{How the system is performing}

The Commission and the EP, as well as academic researchers, have identified several criteria against which the financing system and its components can be assessed. These include economic, political and administrative factors such as revenue sufficiency, simplicity, fairness between Member States and EU financial autonomy. A good system would aim to strike the right balance among the various goals of all these factors; however, these goals may conflict with each other. 
On the positive side, the current system has provided sufficient and stable resources, thus overcoming the financing problems the EU experienced in the 1980s. In general, it is considered to have achieved this result effectively; according to a qualitative analysis by the Commission, the operating costs of the system are likely to be marginal. In addition, actual payments remain below the own resources ceiling. The unused margin under the $1.23 \%$ threshold has served as a guarantee for the European Financial Stabilisation Mechanism (EFSM), the temporary rescue mechanism that the EU created in 2010 to tackle the debt crises.

On the negative side, the Commission's EU Budget Review ${ }^{\mathrm{V}}$ of 2010 notes a series of shortcomings identified by stakeholders, who see the financing system as complex and opaque, and lacking fairness, mainly due to correction mechanisms. In addition, the system relies too much on resources which have little relationship to EU policies and, despite their automaticity, are often considered as national contributions, which Member States aim to minimise. This debate has been running for many years; in a 1999 resolution, for example, the EP presented its analysis of the weaknesses of the financing arrangements, calling for an overhaul of the system. Then, in 2003, the report of a high-level group commissioned by the Commission President (Sapir et al. 2003) highlighted the need for reform of the EU budget, including its revenue side.

\subsection{The thorny debate on balances}

Over time, the debate on the EU budget has increasingly focused on budgetary balances, which measure the difference between contributions to and receipts from the EU budget for each Member State.

Apparently simple, the concept is highly controversial. Estimates of Member States' budgetary balances are necessarily based on assumptions, including that of which items to be considered in calculating revenues and payments. According to the European Commission (1998), "combining only the two or three most important assumptions [...] produces no fewer than 30 to 40 perfectly defensible definitions of budgetary balances", with each of them giving different results - sometimes significantly so for smaller Member States. In many cases, it is difficult to identify the final beneficiary of funds with much precision. For example, Structural Funds are attributed to a Member State, but contracts implementing related projects may be awarded to companies from other Member States. Both students' Member 
Figure 1 - Member States with negative operating budgetary balances (2010-12)*

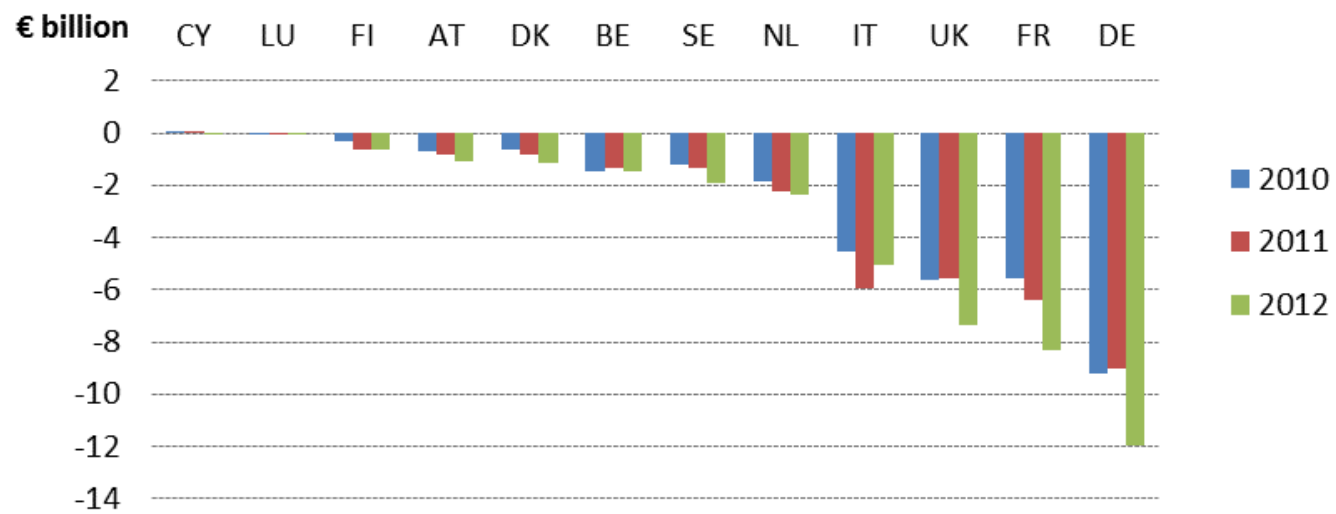

*Cyprus' balance was positive in 2010 and 2011 and negative in 2012. Belgium and Luxembourg have negative balances, but these figures would be more favourable when taking into account administrative expenditure, since the largest EU institutions are mostly located on the territories of these two Member States.

Data source: European Commission.

States of origin, and the countries hosting these same students under Erasmus, can reasonably be expected to benefit from the same funds.

In addition, according to some analyses (e.g. Le Cacheux 2005), the concept is weak from an economic standpoint. As purely an accounting exercise, it results in a "zero-sum game" in which one participant's gains are balanced by another participant's losses. This cannot reflect positive spill-over effects of EU policies. They argue that, on the contrary, European integration would be better seen as a "positive-sum game" from which all participants benefit thanks to achievements such as the internal market. While the Commission publishes operating budgetary balances, it emphasises the fact that this is an accounting allocation which does not provide an exhaustive picture. Neither TOR nor administrative expenditure are taken into account in this calculation.

The excessive focus on budgetary balances (also known as "juste retour" or fair return) is often considered to be one cause of several shortcomings in the current system. It results in decisions that favour instruments with geographically pre-allocated funds rather than those with the highest EU added value, while representing an obstacle to change in the structure of expenditure. In addition, ad hoc correction mechanisms make the system less equitable and have distortive effects. 


\section{The European Parliament's role}

With regard to EU expenditure, the EP is now co-legislator on an equal footing with the Council for the adoption of the annual budget. For the establishment of the EU's longterm financial plans, the Lisbon Treaty sets out that the Council needs Parliament's consent before adopting the Multiannual Financial Framework (MFF).

This is not the case for EU revenue. The Council establishes the own resources system by unanimity after consulting the EP. Some analyses (e.g. Patterson 2011) argue that this asymmetry between the expenditure and revenue sides of the budget sharpens the differences in the perspectives of the two institutions. One limited change introduced by the Lisbon Treaty is that the implementing measures for the own resources system now require the EP's consent before the Council can adopt them (by qualified majority).

A 2007 resolution reflects the critical opinion the EP has of the current system; its structure is considered complex and opaque for EU citizens. In addition, the system has departed from the provisions of the Treaty which aimed to ensure the EU's financial autonomy, because it mainly depends on resources from national budgets. The text called for a reform that should first improve the system of national contributions and subsequently explore new resources, but without increasing overall public expenditure or the tax burden for citizens. The EP also stressed the need to respect fully the principle of fiscal sovereignty of Member States.

In the framework of the negotiations on the 2011 budget, the EP pushed for a reform proposal to be tabled and discussed. Parliament established a Special Committee on Policy Challenges and Budgetary Resources for a Sustainable European Union after 2013. In its report, which the Plenary adopted in June 2011, ${ }^{\mathrm{VI}}$ the Special Committee underlined the link between EU expenditure and the reform of its financing, while calling for a more transparent, simpler and fairer own resources system. Further resolutions ${ }^{\mathrm{VII}}$ reiterated the need for an in-depth reform and the creation of new genuine own resources.

\section{Agreement on 2014-2020 MFF: limited changes in own resources}

\subsection{Commission's reform proposal}

In 2011, the Commission put forward proposals for a Council decision ${ }^{\mathrm{VIII}}$ and four 
related regulations with a view to improving the functioning of the system. The key suggested changes were:

- Member States' contributions would be simplified by abolishing the current VAT resource on 31 December 2013. The European Commission deems that this resource creates administrative burden (complex statistical calculation) without producing real added value (weak link to actual VAT proceeds); it can be seen as a different version of a GNI-based resource rather than as a genuine own resource.

- A financial transaction tax (FTT) resource and a new $V A T$ resource would be introduced (respectively in 2014 and by 2018). They would be more closely related to EU policies and objectives (e.g. with stronger links to VAT harmonisation and actual VAT proceeds for the latter, see below). The resulting revenue would reduce the amounts of national contributions correspondingly.

- As of 2014, a new system of temporary corrections would replace all the mechanisms which existed at that time, for which the underlying conditions have changed significantly since their creation. It would consist of lump sums in favour of Germany, the Netherlands, Sweden and the UK. Furthermore, the "retention rate" for collection costs on TOR would be lowered from $25 \%$ to $10 \%$. This retention rate, says the Commission, can be regarded as a hidden correction, beneficial to Member States that are significant entry points for imports into the EU's single market (e.g. the Netherlands and Belgium).

According to the Commission, these changes would have resulted in a different mix of resources in 2020, with TOR and the two new own resources respectively accounting for $20 \%$ and $40 \%$ of total revenue. The GNI resource would thus have been reduced to $40 \%$. This was expected to decrease the focus on budgetary balances.

However, the Commission's estimates soon became outdated, since no agreement could be reached on the introduction of an FTT at EU level. In the meantime, the Council authorised 11 Member States to move ahead with an FTT by way of the enhanced cooperation method. In its updated proposal, ${ }^{\mathrm{IX}}$ the Commission estimates that an FTT could raise around $€ 31$ billion per year. The press reports that the $11 \mathrm{Member}$ States have conflicting opinions on using part of this potential revenue as an EU own resource. 


\subsection{Reactions and developments}

\subsubsection{European Court of Auditors}

In 2012, the Court of Auditors ${ }^{\mathrm{x}}$ analysed the Commission's proposals; in its opinion, the elimination of the current $V A T$ resource would address a weakness of the system. The new $V A T$ resource is considered complex, but less so than the current one. The Court notes that, being based on volatile economic activity, the revenue raised by an FTT resource would be by nature unpredictable. In addition, it deems lump sum corrections to be simpler than the current mechanisms, but still not transparent. Finally, the amount of TOR in 2020 could be overestimated. The link between the retention rate on TOR and the real collection cost is considered unclear.

\subsubsection{Parliament and European Council}

On 23 October 2012, the $\mathrm{EP}^{\mathrm{XI}}$ asked for the Commission to put forward proposals for new own resources should the new system not result in a significant decrease of the GNI resource. The EP supported ${ }^{\mathrm{XII}}$ the new VAT resource. It called on the Commission to investigate how to further reform it in order for the new own resource to accrue directly to the EU budget.

In February 2013, the European Council reached ${ }^{\mathrm{XIII}}$ the following conclusions on the MFF 2014-20: collection costs on TOR should be lowered to 20\%; a new VAT resource should be further worked on to (potentially) replace the existing one; Member States cooperating on an FTT should examine if this could become an own resource; the UK rebate should be kept; corrections should be granted to Denmark, Germany, the Netherlands and Sweden until 2020 (and to Austria until 2016) by means of lump sum reductions in their GNI-based contribution and/or a reduced rate of call of the VAT resource.

Later that year, the EP succeeded in keeping the debate on own resources high on the political agenda, obtaining the establishment of an inter-institutional high-level group (EP, Council and Commission) tasked with paving the way to possible reforms of the financing system (see Chapter 9).

\subsubsection{Council of the European Union}

In January 2014, the Permanent Representatives Committee of the Council agreed the 
texts of the three legal acts that are meant to implement the February 2013 conclusions of the European Council. These include: the new Own Resources Decision; the regulation setting implementing measures for the Own Resources system; and the regulation establishing how to make Own Resources available. In April 2014, the EP gave its consent to the implementing measures, ${ }^{\mathrm{XIV}}$ whilst it was only consulted in the other two cases. Following adoption by the Council, the three legal texts were published in the Official Journal of the EU on 7 June 2014. ${ }^{\mathrm{xV}}$

Once ratified by Member States, the new Own Resources Decision will apply retroactively as of 1 January 2014. The process can take many months: for example, the current Decision was adopted by the Council in June 2007, but entered into force on 1 March 2009 (after ratification by all Member States), with retroactive effect back to 1 January 2007.

\section{Reform options}

\subsection{Two main models}

According to the mandate set out in the joint declaration, the inter-institutional highlevel group (HLG) will take into account existing and forthcoming input provided by the EP, the Council, the Commission and national parliaments. In the long debate on the reform of the Own Resources system, a wide range of options has been discussed, with two main models emerging:

- One scenario would see the EU budget financed only through a GNI resource. Such a system would be simple. Its supporters consider it would also be fair towards Member States, taking GNI as an indicator of a Member State's ability to pay/contribute. However, the latter assumption is open to debate, given that, for example, the current system of correction mechanisms entails distortions and would need to be reformed. In addition, a reform in this direction is not likely to address the current shortcomings (e.g. the focus on geographically pre-allocated expenditure rather than on initiatives with EU added value) and would go against the spirit of the Treaty, which assigns own resources to the EU so as to ensure the achievements of its objectives.

- The other scenario would imply streamlining the system, with an increase in the 
share of the budget funded by genuine own resources and a corresponding reduction of the resources currently perceived as national contributions. The Commission's 2011 reform proposal went in this direction, building on the Lisbon Treaty, which for the first time explicitly mentions the possibility of establishing new categories of resources and abolishing existing ones. Opponents ${ }^{\mathrm{XVI}}$ of such an approach consider that the "juste retour" attitude is inevitable in EU budgetary discussions, sometimes suggesting other ways of improving the perceived fairness of the system.

\subsection{A few areas of common ground}

Customs duties, and more generally TOR, appear to be suitable EU's own resources. They are closely linked to EU policies and objectives. Since entry points for imports into the EU serve the entire single market and benefit from its existence, it can be reasonably argued that relevant duties are related to the EU level rather than to individual Member States (see section on assessment criteria below). Therefore, there appears to be no real need to eliminate this source of financing for the EU budget. However, TOR currently account for just over $10 \%$ of the resources needed each year and have shown a declining trend over time, due to developments in trade policy.

As long as the EU budget cannot run a deficit, ${ }^{\mathrm{XVII}}$ a balancing resource is necessary. Unlike its predecessor in this role (the VAT resource), the GNI resource has ensured the availability of sufficient resources to finance the EU budget.

Widely recognised as complicated, the current $V A T$ resource does not appear to provide any significant added value to the system and is not perceived as a genuine own resource. According to the Commission, its abolition would only slightly modify Member States' contributions, while simplifying the financing of the budget. However, an obstacle to its elimination lies in the fact that it is an essential component for the calculation of the UK rebate and is therefore linked to the politically sensitive topic of correction mechanisms.

\subsection{Correction mechanisms}

Current correction mechanisms, which only apply to a limited number of Member States, contribute significantly to the opacity of the system. The Treaty does not make any reference to such mechanisms, which rest on the conclusions of the European Council 
held in France in June 1984. According to [these, known as] the Fontainebleau principles, "expenditure policy is ultimately the essential means of resolving the question of budgetary imbalances", but any Member State "sustaining a budgetary burden which is excessive in relation to its relative prosperity may benefit from a correction at the appropriate time". The concepts of excessive budgetary burden and relative prosperity are not defined, remaining open to interpretation.

In 2011, the European Commission presented examples of data (see table 2), indicating that there was no clear correlation between net contributions and relative prosperity under current arrangements and in a context that had significantly evolved since 1984 (lower share of the EU budget devoted to agriculture spending; increased relative prosperity of the $\mathrm{UK}$; and significantly reduced role of the VAT resource in the mix of resources financing the EU budget). ${ }^{\mathrm{XVIII}}$ The Commission also considered that existing net contributions were generally low. In addition, the UK rebate can have a distortive effect on UK expenditure of EU funds, potentially making their use less interesting for the country. For example, if the UK obtains resources under the European Union Solidarity Fund, which provides support in the event of major natural disasters, in practice the actual aid received will be reduced by two-thirds due to the mechanism of the rebate.

Table 2 - Prosperity and net contributions

\begin{tabular}{|l|r|r|}
\hline & $\begin{array}{l}\text { Operating budgetary balances } \\
\text { average 2007-2010 (\% GNI) }\end{array}$ & $\begin{array}{l}\text { Prosperity 2010 } \\
\text { (GNI pc PPS, EU-27=100) }\end{array}$ \\
\hline Denmark & $-0.29 \%$ & 127.0 \\
\hline Germany & $-0.32 \%$ & 120.2 \\
\hline France & $-0.23 \%$ & 108.7 \\
\hline Italy & $-0.26 \%$ & 98.2 \\
\hline Netherlands & $-0.31 \%$ & 134.4 \\
\hline Austria & $-0.18 \%$ & 124.7 \\
\hline Finland & $-0.19 \%$ & 117.3 \\
\hline Sweden & $-0.27 \%$ & 125.3 \\
\hline United Kingdom & $-0.17 \%$ & 115.5 \\
\hline
\end{tabular}

Data source: European Commission (2011).

On the basis of these considerations, the Commission has repeatedly tried to reform 
correction mechanisms, by putting forward proposals for a general correction mechanism applicable to all Member States (2004) or a system based on temporary lump sums for a limited number of countries (2011). However, the issue has proved to be politically sensitive, with relatively limited changes agreed by Member States after both proposals. In discussions in 2012, many delegations favoured ${ }^{\mathrm{XIX}}$ the abolition of all corrections. According to the Court of Auditors (2005), ${ }^{\mathrm{xx}}$ the existence of any correction mechanism has a negative impact on the simplicity and transparency of the system.

\subsection{Should the EU budget have some redistributive effects?}

In 1957, the Treaty of Rome mentioned the need to promote harmonious economic development and help less favoured regions close the gap they experience. At the time the UK rebate was created in 1984-85, 69\% of the EU budget was spent on agriculture. On the

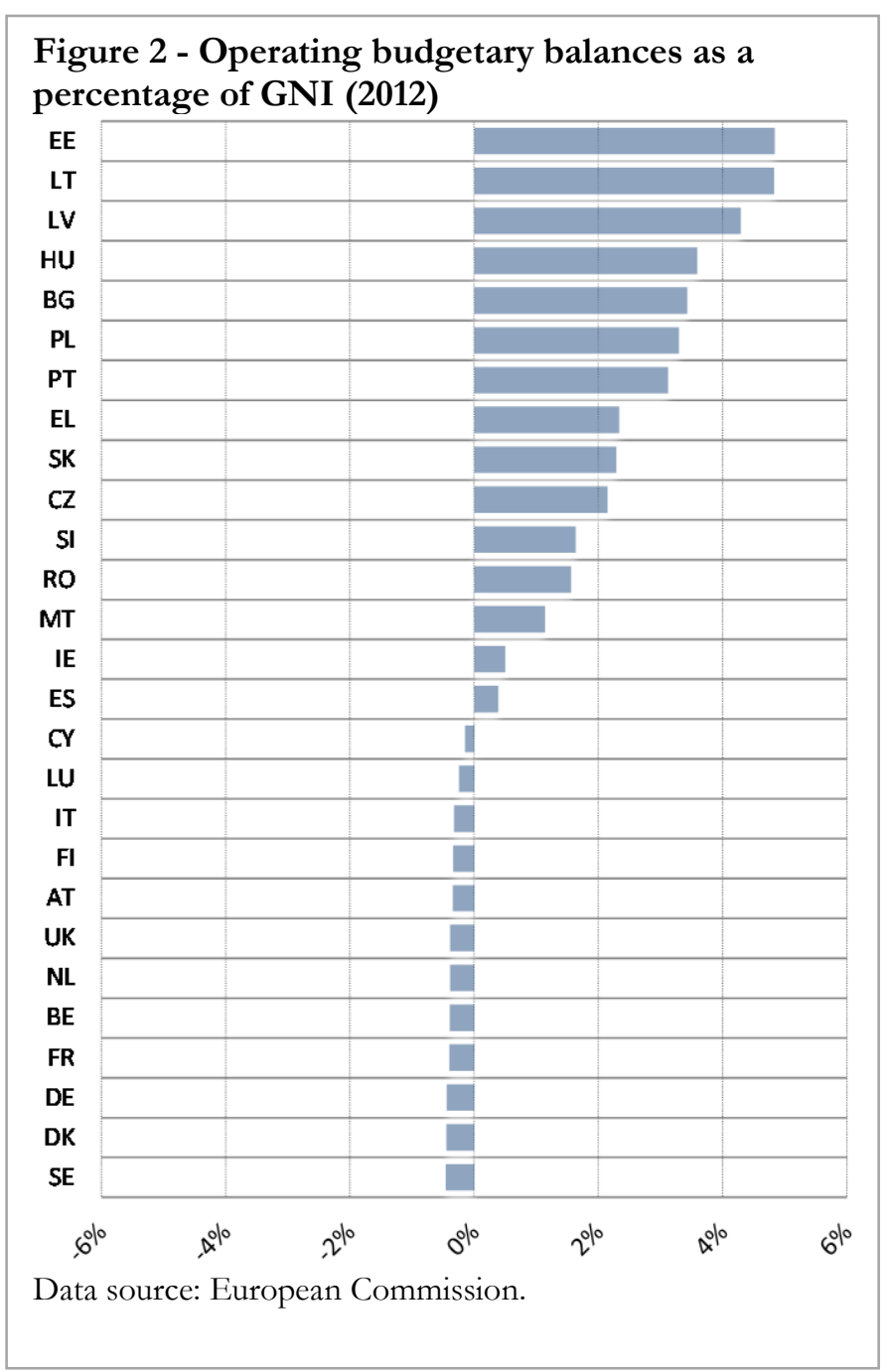
one hand, agriculture was (and still is) a policy area with spending mainly concentrated at EU level. On the other hand, EU agriculture spending had redistributive effects that did not appear necessarily to be related to countries' relative prosperity.

Subsequent years saw a significant increase in the resources assigned to cohesion policies ${ }^{\mathrm{XXI}}$ with redistributive objectives clearly related to relative prosperity. This trend aimed at counterbalancing the impact of the completion of the single market on less developed Member States and regions, but can also, in part, be seen as an attempt to implement the first Fontaineblean principle (expenditure policy as the main tool to address budgetary imbalances), by reducing 
the share of the budget devoted to agriculture expenditure. ${ }^{\mathrm{XII}}$ However, the European Commission notes that Member States with lower relative prosperity currently contribute to financing correction mechanisms, which results in a partial neutralisation of cohesion objectives. At the same time, geographically pre-allocated resources play a role in increasing the focus on budgetary balances, but some analysts consider that overall the EU budget has rather modest redistributive effects, due to its size and capping. Nonetheless, for some countries, the EU budget may represent a significant source of resources for investment: for central and eastern European Member States, for example, the very rough indication given by operational budgetary balances shows positive annual surpluses, in most cases corresponding to between $2.14 \%$ and 4.84\% of GNI in 2012 (see figure 2). Enderlein et al. (2012) note the need to address persistent structural divergences so as to build a more balanced EU.

\section{Criteria to assess the system and/or its components}

In the long debate over possible reforms of the own resources system, many analyses have been carried out at both an institutional (e.g. EP and European Commission) and an academic level since the 1970s. Each of them identifies sets of criteria against which individual resources and/or the system as a whole can be assessed, taking into account both elements of tax theory and the unique institutional configuration of the EU. Even if they partly differ in their definition or scope, many criteria recur in most analyses, as pointed out in a 2008 study carried out for the European Commission (Begg et al. 2008). A non-exhaustive list of criteria can be organised in six broad categories, though some criteria can relate to more than one category

\subsection{Budgetary criteria}

These include sufficiency and yield stability. The system needs to provide resources that are sufficient to cover agreed expenditure, and are reasonably stable over time to avert the risk of sudden financing difficulties. These principles should also apply to the selection of new own resources given that reforming the system has proved to be a long and difficult process. For example, it can be argued that it may not be efficient to introduce a new own resource whose expected proceeds would be small in comparison with the size of the EU 
budget, highly volatile and/or likely to be on a downward path. The financing problems experienced in the 1980s show the importance of budgetary criteria.

\subsection{Democratic accountability criteria}

Since the EU is a Union of States and citizens, the financing system and its components should be characterised by simplicity, transparency (both explicitly mentioned in the mandate of the HLG) and visibility so as to allow a closer bond between the Union and its citizens. The Treaty principle of EU financial autonomy, which some analysts (Heinemann et al. 2008) do not recognise as a criterion proper, could also be seen as part of this category.

\subsection{Economic criteria}

In principle, the system and its components should distort economic choices as little as possible, for example not discriminating against individual sectors (neutrality). However, in the case of economic activities producing transnational negative externalities, ${ }^{\text {XIII }}$ the system or one of its resources could be designed to address a market imperfection (socalled corrective or "Pigouvian" taxation), in line with EU policy objectives (e.g. environmental goals).

\subsection{Equity criteria}

The system should take into account the ability to pay. Entities in similar situations should each provide a similar contribution. Regressive aspects, implying a proportionally higher contribution from those worse off, should be avoided. In tax theory, these concepts apply to equity between citizens. In the EU context, they are also often related to the objective of ensuring fairness between Member States. Equity is another of the guiding principles mentioned in the joint declaration on the high-level group.

\subsection{Integration criteria}

The link to a common EU policy can strengthen the rationale for assigning a resource to the EU level. In addition, fiscal theory speaks of regional arbitrariness, when the tax base cannot be easily linked to the place where the tax is collected and there is potentially a high mismatch between the collection and the burden of a tax. TOR provide a practical example 
of this concept: customs duties are collected in the Member State where the goods enter the EU's internal market, but their burden may be borne by economic agents who are resident in other Member States depending on the destination of the goods. Therefore, the assignment of customs duties to the EU level appears to make sense, given that entry points of goods benefit from the existence of the EU's internal market, and it is difficult to determine how relevant revenue should be shared between individual Member States.

\subsection{Technical and administrative criteria}

Cost-effectiveness should characterise the collection of resources. This means that administrative costs need to be low in comparison with the proceeds. At the level of individual resources, this objective can be favoured by a number of factors such as: the existence of a harmonised base for the resource; a reasonably short time needed for implementation once the resource has been selected; and the absence of any major potential legal issues for implementation.

\section{The need for prioritisation}

The perfect resource does not exist, since the various goals of all these factors may partly conflict with each other. In any case, a prioritisation of objectives, which implies a certain degree of subjectivity, is needed to launch a reform of the system. The joint declaration on the HLG appears to provide some indications to this effect. However, different stakeholders have so far shown different preferences. A good system and its components would aim to strike a balance among the various criteria, possibly resorting to a mix of resources.

\section{The two new resources proposed by the Commission in 2011}

In the EU budget review of 2010, the European Commission identified six financing means as possible new own resources for the budget of the Union:

- taxation of the financial sector;

- revenues from auctioning under the EU's greenhouse gas Emissions Trading System (ETS);

- a charge related to air transport;

- energy tax;

- VAT;

- and corporate income tax. 
The 2011 report on the operation of the own resources system presents an analysis of each hypothesis (usually including some variants). Its annex briefly explains the reasons why two additional options, (an EU communications tax; and a resource related to seigniorage, part of the monetary income that the euro area central bank system derives from its activities), were discarded. The two documents show the grounds on which the Commission selected VAT and financial transactions for its reform proposal.

\subsection{A new VAT resource}

The variant of the VAT resource put forward by the Commission in 2011 aims to create a closer link between actual VAT receipts in Member States and the EU budget. While simplifying the calculation in comparison with the current system, it would focus only on the final consumption of goods and services that are subject to the standard VAT rate in each and every Member State, ${ }^{\text {XXIV }}$ with a share of relevant VAT proceeds assigned to the EU. This narrow base is meant to overcome the issues created by the incomplete harmonisation of VAT across the EU that triggered the transformation of the current resource into a mainly statistical tool through a long series of corrections and compensations (e.g. capping of the base).

The European Commission considers that such a VAT resource would have a series of positive features. It would provide a significant yield, but be subject to limited volatility: applying a 1\% EU rate to 2009 data, revenues for the EU budget were estimated at between $€ 20.9$ billion (with the current degree of harmonisation of VAT rules in the EU) and $€ 50.4$ billion (with further harmonisation of VAT rules). While increasing simplicity and visibility in comparison with the current system, such a resource would not create a disproportionate burden for specific sectors, says the Commission. ${ }^{\mathrm{Xxv}}$ In addition, it is linked to EU policy objectives, with further on-going efforts to streamline VAT provisions and thus strengthen the single market. ${ }^{\text {XxVI }}$ As regards cost-effectiveness, the selected option is said to be the variant with the more limited impact on businesses and national administrations.

According to an analysis (Schratzenstaller 2013) based on partially different criteria, VAT would qualify as a suitable base for a genuine EU own resource only for its long-term yield and visibility, but not so against other parameters. Conversely, another paper (d'Oultremont et al. 2013) considers that a new VAT resource would improve the current 
system in many respects, while noting the possible difficulties in reaching an agreement at the political level. The decision-making process is mentioned as the main short-term obstacle (ahead of the regressive character of VAT and different levels of VAT fraud across the EU) to the adoption of a new VAT resource in another article (Leen 2013), which assesses the pros and cons of such a source of revenue. Commenting on its 2011 estimates, the Commission says that the VAT burden in some Member States (e.g. Cyprus, Luxembourg and Malta) would be higher than average, but argues that the regressive aspects of VAT are not clear-cut and that different consumption patterns could also be due in part to factors such as cross-border shopping and tourism.

\section{Where the new VAT resource proposal stands}

The EP has supported the introduction of a new VAT resource, identifying transparency, fairness to taxpayers in all Member States, and improved simplicity as its main advantages and calling for proposals to reform this resource further. The European Council has not ruled out the replacement of the current VAT resource with a new one, but has called for further work by the Council. Whilst the European Commission had identified 2018 as the target date for introduction of the new VAT resource, this was postponed to 2021 in an interim document prepared by the President of the European Council during the MFF negotiations. The conclusions of the European Council on the MFF do not include any precise date for the introduction of the new resource. In any case, the proposal remains on the table for consideration by the HLG in the wider review of the system.

\subsection{An FT'T resource}

In the wake of the financial crisis, the idea of taxing the financial sector was revived. After examining several options to this end, the European Commission recognised some positive aspects in a Financial Activities Tax (FAT), but highlighted also a series of obstacles an FAT would face (e.g. from an administrative and political standpoint along lines that are similar to those identified for a hypothetical EU corporate income taxation, see section on other potential candidates below). On these grounds, the Commission deemed financial transactions to be a more suitable tax base in a first phase and put forward a proposal for an EU-wide FTT, suggesting that the revenue of this new source be shared among national budgets (one-third of the receipts) and the EU budget (two-thirds).

The reasons advanced for using part of an FT'T as an own resource include economic criteria; the financial sector is deemed to enjoy a tax advantage due to the current VAT exemption on most financial services, while it benefitted from huge state aid measures during the crisis. The sector would repay part of these costs through such a scheme, which 
would aim to curb the volume of speculative financial transactions and reduce the volatility of the market (thus addressing negative externalities). These objectives would be better achieved at the EU level, due to the high mobility of the tax base. In addition, an FT'T may contribute to EU policies (e.g. by strengthening the internal market) and has a potentially high yield (according to the initial Commission estimates, a variant limited to a low rate on transactions between financial institutions could raise between $€ 30$ billion and $€ 50$ billion per year for the EU-27 by 2020). Such an own resource could be perceived as unfair towards some Member States, since a high volume of financial transactions is concentrated in a few Member States. However, in the context of the single market, the European Commission considers that the proceeds would be characterised by regional arbitrariness, since they would not necessarily be attributable to the country in which a transaction takes place.

On the negative side, the European Court of Auditors notes the high volatility of financial transactions, which would result in unpredictability of revenue. In addition, the economic effects of an FTT are controversial and much debated in the literature, with opponents arguing that it can have a negative impact on the economy without being able to reduce market volatility or speculative transactions. For example, Kaiding (2014) considers that an FTT does not qualify as a Pigouvian tax, suggesting that a reform of VAT on financial services ${ }^{\mathrm{XXVII}}$ or an FAT would be more suitable solutions to address the tax advantage of the financial sector. An additional criticism of an FTT is that it would have low visibility for citizens. ${ }^{\mathrm{xxvIII}}$

Conversely, Schratzenstaller (2013) concludes that an FT'T is the most suitable base for a new own resource among the options examined by the European Commission in 2011, while recalling that there are no resources able to meet all the assessment criteria. Another analysis (d'Oultremont et al. 2013) considers that the economic effects of an FTT will largely depend on its final design and gives a positive overall assessment of this option.

\section{Where the FTT proposal stands}

The idea of establishing an FTT at EU level encountered strong opposition from a number of Member States, including the UK and Sweden. Following an updated Commission proposal, 11 Member States (Belgium, Germany, Estonia, Greece, Spain, France, Italy, Austria, Portugal, Slovenia and Slovakia) decided to cooperate to introduce an FTT by way of the enhanced cooperation method. In April 2014, the Court of Justice of the EU dismissed an actionXXIX brought by the UK against the Council decision authorising this move. The EP, which had repeatedly called 
for the introduction of an FT'T at global and European level, gave its consent to the creation of an FTT under enhanced cooperation. Updated Commission estimates indicate that annual proceeds could amount to around $€ 30-35$ billion under the new proposal. The European Council conclusions on the MFF left the door open to the possibility of using part of this revenue to finance the EU budget. This would correspondingly reduce GNI-based contributions. However, it remains to be seen whether such a solution - if agreed upon by participating countries - would help to address the current shortcomings of the system; a resource stemming from only some Member States would not increase its simplicity, while net balances would be likely to remain the main logic and the benchmark underpinning budgetary debates. While participating countries initially planned the launch of the first phase of the FT'T by 1 January 2016, xxx negotiations have repeatedly been beset by difficulties and delays. XxxI

\section{New own resources: other possible candidates}

In the run-up to the completion of the review of the own resources system, it may also be worth reconsidering the options that the Commission did not retain in its reform proposal.

\subsection{Revenues from the EU Emissions Trading System (ETS)}

The ETS is the centre-piece of EU policy to fight climate change. It sets limits on the total quantities of certain greenhouse gases which entities in the scheme (e.g. industrial installations) can emit, while emission allowances can be traded by these entities within the established limits. Revenues stemming from the allowances auctioned under the ETS could be shared between EU and national budgets. Contrary to tax-based own resources, the revenue would thus depend on the prices of allowances determined by demand and supply on the relevant market.

Elements in favour of the use of ETS revenue as an own resource include: the clear link to an EU policy and economic criteria with neutrality towards installations already subject to ETS rules; as well as the possibility of further addressing negative externalities (e.g. by earmarking relevant revenue for additional environmental actions, even if current provisions already include targets to this end).

Among the risks to be minimised, the European Commission notes that re-opening negotiations on the ETS Directive could affect the legal certainty of the scheme, which is needed for its good functioning. In addition, fairness between Member States could be a source of friction, since significant differences can be observed in the distribution of auction rights, whose allocation is reported to have played an important role in the final 
agreement on the climate and energy package.

According to Commission estimates from 2011, ETS revenues accruing to the EU budget could reach $€ 20$ billion in 2020 . As noted above, market factors would have a direct impact on the actual proceeds. In the meantime, the functioning of the ETS has raised criticism, with some analysts ${ }^{\mathrm{XxXII}}$ arguing that it is a flawed policy and identifying a gradually rising carbon tax as a better means of meeting carbon reduction objectives.

A 2014 IMF working paper argued that national considerations alone would already justify a substantial carbon tax (or $\mathrm{CO}_{2}$ pricing through trading systems), estimating the average efficient price for the top twenty emitters at USD57.5 per tonne of $\mathrm{CO}_{2}$ (but with significant variations from one country to another), and noting that this was much higher than the recent prices in the EU's ETS.

In 2015, following a Commission proposal to tackle the over-supply of allowances in the ETS, Parliament and Council agreed to introduce a new mechanism under which surplus allowances would be placed in a Market Stability Reserve, starting in 2019. According to data by Thomson Reuters Point Carbon, the price of emissions allowances will go from $€ 7.50$ in 2015 to $€ 19$ by 2020 . Point Carbon's analysis adds that the reform should allow governments to increase their revenue from emissions auctions by $89 \%$ (with the total revenue between 2015 and 2025 now estimated at $€ 151$ billion). xxxIII

\subsection{Charge related to air transport}

The liberalisation of the EU air transport market is regarded as a success story, with significant economic benefits for the wider economy. While, in comparison with other activities (including road and rail transport), the sector enjoys a favourable tax regime with virtually no taxation of kerosene and no VAT on air tickets, some Member States have introduced national air passenger taxes. The ETS, which is applicable to air transport since 2012, has also ignited a debate in this sector.

According to the Commission, integration criteria would support the establishment of an air transport duty (either on passengers or on flights) at the EU level rather than at the national level, so as to avoid fragmenting the internal market and distorting competition. In addition, companies' relocation of activities undermined attempts by some Member States (e.g. smaller ones) to introduce such a duty, suggesting that the national level is not the optimal one for this. Cost-effectiveness considerations could also play a positive role, as 
shown by the example of some national air duties which needed only a few months to be introduced.

While the uneven distribution of air transport across the EU could raise equity issues, the European Commission argues that air transport activities are characterised by a degree of regional arbitrariness due to their cross-border nature. In relation to economic criteria, the analysis notes the need for careful design of the scheme, for example to avoid a negative impact on the international competitiveness of EU air transport and on the economy of regions that are much dependent on air transport due to their geographical features. The example of the UK Air Passenger Duty (APD), in force since November 1994, is presented to support the idea that such a scheme can function, and that its potential negative impact should not be overestimated.

An air transport duty could provide a significant yield, estimated at $€ 20$ billion or more in 2020. Since the cyclical nature of the sector would entail some volatility in the proceeds, its use in a mix with other resources should be considered.

Schratzenstaller (2013) agrees that a charge based on air transport would qualify well as an own resource of the EU, noting that it would also meet the visibility criterion. If this option was chosen, opposition from the industry might be expected; for example, a group of UK and Irish companies commissioned a study to measure the impact of the abolition of the UK APD on the economy and on public finances. In addition, there has been much debate on the differentiated application of the UK APD in Scotland and Northern Ireland.

\subsection{Energy/carbon tax}

A framework for various aspects of energy taxation in the EU is set by Council Directive 2003/96/EC (Energy Taxation Directive, or ETD), which the European Commission proposed to amend in 2011. ${ }^{\text {XxIV }}$ This basis could facilitate the introduction of an energy-related own resource. However, in March 2015 the Commission withdrew its proposal for an amendment of the energy taxation framework on the grounds that Council negotiations had resulted in a draft compromise text that completely distorted the substance of the proposal. In addition, there was not even agreement in the Council on the compromise text.

In 2011, the Commission identified two main options (each with several possible variants): an energy levy (linked to energy products released for consumption); and a 
carbon levy. The latter would require the adoption of the amended ETD and could complement the ETS so as to ensure a coherent approach and avoid overlaps in the policy to fight $\mathrm{CO}_{2}$ emissions.

Under the integration criteria supporting the establishment of an own resource in this field, the link to an EU policy and attempts to strengthen the internal market for energy could be envisaged. For example, the new resource could be used to finance part of the significant EU energy infrastructure needs that have been identified by the European Commission.

In the case of a carbon levy in particular, economic criteria would include the goal of addressing negative externalities. According to the Commission, neither option would automatically imply a different tax burden for the energy or other sectors, since these levies would mainly determine a transfer of some resources from Member States to the EU budget. Their final effect would depend on how Member States adapted their national tax rates. The need to analyse in further detail the potential impact of even a limited price increase on the competitiveness of EU industry is underlined. In recent years, energy prices rises and divergences in the EU have been a source of concern; a 2014 Commission communication $^{\mathrm{Xxx}}$ analyses the topic, with particular focus on electricity and gas prices.

As regards budgetary criteria, rough estimates show a significant yield. For example, an energy levy could provide the EU budget with between $€ 17.5$ billion (when assuming an EU levy on petrol and diesel used as road motor fuel of $€ 50$ for 1000 litres) and $€ 21.8$ billion (when broadening the scope of the levy). Proceeds from a carbon levy could be even higher, but they might gradually decrease over time, as $\mathrm{CO}_{2}$ reduction targets are progressively met.

In relation to equity criteria, the European Commission calculates that an energy or carbon-levy-based own resource would modify the current shares of Member State contributions to the EU budget, with those countries having a more energy- and/or carbon-intensive economy expected to contribute more. As regards in particular a resource based on excise duties on road transport fuel, more prosperous Member States would contribute a proportionally lower share of their GDP, but significantly higher amounts in absolute terms. 


\subsection{EU Corporate Income Tax (EUCIT)}

The taxation of corporate income is largely diversified and uncoordinated across the $\mathrm{EU}$. The Commission considers that this hampers the functioning of the single market, not least by creating red tape for companies that operate in more than one Member State. To address this issue, in 2011 the Commission put forward a proposal to create a Common Consolidated Corporate Tax base (CCCTB) for the EU-wide activities of these companies. The EP supported the proposal, which has stalled in the Council, facing difficult negotiations.

On 17 June 2015, the Juncker Commission presented an Action Plan for Fair and Efficient Corporate Taxation in the EU, which includes the re-launch of the CCCTB proposal. Stressing the CCCTB's potential as an anti-tax avoidance tool, the Commission declared that it would present an updated proposal in 2016, with a mandatory CCCTB (at least for multinational companies) and a step-by-step approach, organising the original proposal into different and smaller stages to facilitate agreement in the Council: 1) a definition of the common base; and 2) consolidation. The end-result would be a system in which countries share the consolidated tax base and divide the related revenue on the basis of a formula (some countries with federal-type fiscal frameworks such as the USA, Canada and Switzerland are already using these so-called 'formulary apportionment systems'). The business lobby group BusinessEurope immediately withdrew its support for the Commission initiative on the grounds that the СССТВ would be mandatory under the new proposal (contrary to the 2011 proposal).

An own resource assigning part of corporate income taxation proceeds to the EU, or EUCIT, would have a broader scope than a CCCTB. In its declaration of 17 June 2015, the Commission says that the CCCTB is not a first step towards the harmonisation of tax rates. A company's taxable profits would be "shared out between the Member States in which the company is active, according to an agreed formula. Each Member State would tax their share of the profits at their own national rate."

Integration criteria supporting a EUCIT could include not only the possible strengthening of the single market, but also aspects related to regional arbitrariness. For example, Schratzenstaller (2013) notes that location of activities is increasingly severed from the place where related profits are taxed. Budgetary criteria suggest that the EUCIT could produce a high yield (estimated by the Commission at $€ 15$ billion per year with a tax 
rate lower than $2 \%$ ), but it would be volatile due to the cyclical nature of the tax base.

As regards economic criteria, the European Commission indicates that there could be a higher impact on certain sectors and the cost of adaptation to the EUCIT could be high for businesses active only in one Member State. Technical and administrative aspects might create difficulties as well. Last but not least, in past analyses of the own resources system the Commission did not appear to consider the EUCIT a feasible option for the near future, due to the high political sensitivity of the corporate income taxation area.

The Commission Action Plan for Fair and Efficient Corporate Taxation should be seen in the wider context of the international debate on how to reform corporate taxation and tackle tax avoidance, and notably the work of the OECD Task Force on Base Erosion and Profit Shifting or BEPS (see Section 8.6). In 2015, an Independent Commission for the Reform of International Corporate Taxation, including Nobel-prize winning economist Joseph Stiglitz, called for broad reform of the system, considering, among other points, that the current 'separate entity' principle is fictitious and that multinational firms should be considered and taxed as a single entity at global level. According to the Financial Times, Pascal Saint-Amans, Director of the Centre for Tax Policy and Administration in the OECD, said that the proposal for a 'formulary apportionment system' at global level lacks pragmatism, while he agreed that the BEPS project should take the views and needs of developing countries more clearly into account.

Peeters (2015) considers that the introduction of a EUCIT would have many advantages, including contributing to progress at EU level on the OECD Action Plan on BEPS.

\subsection{A resource related to seigniorage}

Seigniorage is a form of monetary income that central banks derive from their monopoly position in issuing notes. In the euro area, seignioriage is currently distributed by the European Central Bank to the National Central Banks of the countries whose currency is the euro. From time to time, it has been suggested that seigniorage related to the euro be attributed to the EU budget instead. In its 2011 report, the European Commission recalled that it has already analysed this hypothesis on previous occasions, discarding it on various grounds. In addition to legal and institutional obstacles, the Commission considers that such a resource would produce a limited yield in comparison with the size of the EU 
budget.

The fact that the Union has exclusive competence in monetary policy for the Member States whose currency is the euro is one argument in favour of using seigniorage or monetary income as source of financing for the common budget. A 2008 study carried out by I. Begg, H. Enderlein, J. Le Cacheux and M. Mrakfor for the Commission says that the seigniorage income on euro holdings outside the euro area cannot be easily assigned to any specific country and thus belongs rather to the euro area as a whole. Leen (2012c) draws a parallel between monetary income and custom duties, arguing that in a common currency area there is no obvious allocation key for the monetary income among participating countries (just like it would be rather arbitrary to assign custom duties to the country where related imports first enter a single market).

However, the common monetary policy is currently limited to 19 EU countries. Thus, it would be necessary to design an alternative resource for the countries that have not adopted the euro. This would add a layer of complexity to the financing of the EU budget; and this need to create a two-tier mechanism for euro area and non-euro area countries is another reason why in 2011 the European Commission discarded the idea of an own resource based on seigniorage.

The European Central Bank and National Central Banks are opposed to the idea of attributing euro area seigniorage to the EU budget, which, according to some observers, could be perceived as a limitation of their independence. Conversely, Leen (2012c) considers that, due to its link to an EU policy, seigniorage would qualify well as an own resource, while estimating that relevant proceeds would not be negligible and could cover up to a quarter of the EU budget, although would be volatile.

\subsection{An EU communications tax}

In its 2011 report, the European Commission discarded ideas for own resources related to communication activities such as telecommunications, deeming their rationale difficult to justify (in the absence of clear externalities to be addressed) and possibly even contrary to EU policy objectives (e.g. Digital Agenda for Europe and roaming price reductions across voice calls, SMS and data in the single market).

Leen (2012b) focused on the idea of an Internet communication tax at EU level, but agreed that in the current framework this would not be a feasible option, despite having 
some positive aspects (e.g. as far as visibility, equity and neutrality are concerned). According to the author, the acceptability of such a scheme might evolve in the future, for example with EU resources allocated to cross-border investments in digital infrastructure for the single market, but technical aspects would need to be investigated in further detail.

Tarschys (2015) argues that the digital economy is dramatically changing the fiscal landscape, drawing attention to risks such as loss of territorial control and fiscal mobility. According to the author, the EU should look for new EU own resources among tax bases (often linked to the digital economy) which escape individual governments, and can only be tapped through joint action. The author adds that much research is still needed to explore these possibilities.

Indeed, internet companies are often seen as a prominent example of aggressive tax avoidance strategies. In 2014, in the context of a project launched by the G20, the OECD published an intermediary report ${ }^{\mathrm{XXXVI}}$ on addressing the tax challenges of the digital economy, concluding that, since the digital economy is becoming the economy itself, it would be very difficult to separate it from the rest of the economy for tax purposes. Therefore, Base Erosion and Profit Shifting (BEPS) risks should be addressed in a comprehensive tax regime including the digital economy. In May 2014, a Commission Expert Group on Taxation of the Digital Economy (chaired by Vítor Gaspar, a former finance minister of Portugal) delivered its final report. This came to the same conclusion, that digital companies should not be subject to a special tax regime, and said that "the only immediate practical way forward at the global level is via the G20/OECD BEPS project". Among other points, the report of the Commission expert group calls for a thorough review of the concepts relevant for defining and applying the taxable presence of a company in a country, with a focus on two features:

- "The Group supports work within the G20/OECD BEPS Project considering whether and under what circumstances sales of goods or services of one company in a multinational group should be treated as effectively concluded by dependent agents."

- "When defining exceptions to the concept of a Permanent Establishment (PE), the Group recommends taking into account that the digitalisation of the economy may have changed the distinction between auxiliary activities and core activities." 
On 5 October 2015, the OECD presented the final package of measures for a reform of the international tax rules.

\section{The high-level group on own resources}

\subsection{Composition and mandate}

In February 2014, the EP, the Council and the European Commission officially launched the high-level group (HLG) on own resources, establishing for the first time an inter-institutional group tasked with a thorough review of the own resources system, and involving the EP.

Each of the three institutions appointed three members of the group, while jointly choosing Mario Monti, President of Bocconi University, former Prime Minister of Italy and former Commissioner, as its chair. On 3 April 2014, the first meeting of the HLG took place in Brussels, with three subsequent meetings during the year. The composition of the HLG was partially modified following the entry into office of the new European Commission, with the replacement of the members of the HLG appointed by the previous Commission. In addition to the chair, the current nine members are:

- Ivailo Kalfin (former MEP, Deputy Prime Minister of Bulgaria and Minister of Labour and Social Policy), Alain Lamassoure (French MEP in the EPP group) and Guy Verhofstadt (Belgian MEP, chair of the ALDE group), appointed by the EP;

- Daniel Dăianu (former MEP and Finance Minister of Romania), Clemens Fuest (President of the Centre for European Economic Research ZEW in Germany) and Ingrida Šimonytė (former Minister of Finance of Lithuania), appointed by the Council; and

- Kristalina Georgieva (Vice-President of the Commission in charge of budget and human resources), Pierre Moscovici (Commissioner for economic and financial affairs, taxation and customs) and Frans Timmermans (First Vice-President of the Commission responsible for better regulation, inter-institutional relations, rule of law and Charter of Fundamental Rights).

The joint declaration of the three EU institutions defines the mandate of the HLG, detailing the four guiding principles for the review of the own resources system: 1) simplicity; 2) transparency; 3) equity; and 4) democratic accountability. 
The HLG is meant to drive discussion forward on the future of the own resources system, with its final report of 2016 potentially leading to new reform proposals from the Commission. Its work is to be based on both existing and new analyses provided by the three institutions and national parliaments, and to draw on relevant expertise.

\subsection{The first assessment report}

On 17 December 2014, Mario Monti presented the first assessment report of the HLG to the Presidents of the three institutions that created the group. The document recaps the key features of the current system, singles out those that are perceived by stakeholders as requiring modifications, and analyses the most recent (and, by and large, unsuccessful) reform proposals. In addition, the group sketches out some elements of the methodological approach that will guide its work and be set out in more detail in the months to come. Members of the group underline that they take part in the deliberations as individuals rather than as representatives of the institutions that appointed them.

An intermediary and tentative conclusion is that the financing system of the EU has not experienced any major modifications over the last 25 years, proving difficult to change. However, the group notes that keeping reform of the own resources system on the political agenda shows that European stakeholders are aware that progress in this area could help tap the full economic potential of the EU budget and focus on issues of European common interest. A precondition for any progress, the report adds, is that all those involved in any overhaul of the system acknowledge that, from both an economic and a political perspective, the EU budget has positive spill-over effects, thus representing much more than a zero-sum game with net beneficiaries and net contributors.

\subsection{Perceived shortcomings of the system}

While observing that some stakeholders do not see any major reasons to change the current way of financing the EU budget, the assessment report recapitulates the main shortcomings of the system perceived by others. These include complexity and lack of transparency, notably in relation to the wide range of correction mechanisms and to the configuration of the current VAT-based resource. Another section of the report says that one effect of the correction mechanisms and their financing is that the current system of national contributions could be seen as regressive overall, meaning that less affluent ${ }^{\mathrm{xx} x \mathrm{II}}$ 
Member States do not contribute proportionally less to the EU budget. ${ }^{\text {XXXVIII }}$

The key role gained over time by GNI- and VAT-based resources (providing more than $80 \%$ of total revenue in 2013), which are perceived as national contributions rather than as genuine own resources of the $\mathrm{EU}$, is said to have sharpened the difference in perspectives between countries classified as net beneficiaries of, or net contributors to, the EU budget, with a potential negative impact on the focus and effectiveness of EU spending. GNI and VAT resources are both based on statistical calculations that had never been questioned until recently, when higher-than-usual annual adjustments of the relevant statistical aggregates brought their technical aspects into the spotlight.

In addition, according to the report, some limits of the EU's financing system have been exposed by the economic crisis, and the fiscal difficulties that this has triggered at the national level. The text draws a link between the above-mentioned criticisms of resources perceived as national contributions and the year-end backlog of payments that has afflicted the EU budget in recent years, given that in many national budgets the contribution to the EU budget appears as an item of expenditure.

Last, but not least, attention is drawn to the very complex decision-making mechanism for changes to the rules of the system, which requires unanimity and ratification by all Member States. While attributing to this aspect much of the failure of major reform proposals up to now, the group points to the need to draw lessons from the latest negotiations to ensure progress in future.

\subsection{Some methodological elements}

The first report sketches out some of the methodological elements that will inform the HLG's deliberations, so as to avoid the gridlock in which past proposals have resulted. While any proposals will need to be sound from an economic and budgetary standpoint in order to succeed, their success will also depend on a careful consideration of the institutional and political aspects of the process, including the clustering of decision-makers in subgroups sharing the same interests and objectives.

Along these lines, the report identifies a set of criteria against which to evaluate the operation of the own resources system, placing them in two categories:

- five general economic and financial criteria (equity/fairness; efficiency; sufficiency and stability; transparency and simplicity; democratic accountability and budgetary 
discipline); and

- three EU-specific criteria (focus on European added value and constraining narrow selfinterest; the subsidiarity principle and fiscal sovereignty of Member States; and limiting political transaction costs).

The HLG has selected and defined these criteria, building on the guiding principles set out in the mandate given by the institutions, and taking into account recent analyses of the topic. The report notes that the exercise implies a certain degree of subjectivity, with some criteria appearing more difficult to unequivocally define and interpret than others. For example, experience is said to show not only that the various decision-makers may have very different interpretations of fairness, but also that each interpretation may change over time, depending on domestic priorities.

In addition, individual criteria may partially conflict with each other. The report therefore says that viable reform recommendations should entail a mix of different own resources, since jointly these can meet a higher number of criteria.

\subsection{Towards the final report}

Considering that substantial analyses on the functioning of, and possible changes to, the own resources system already exist, the HLG expressed its intention to focus in particular on the broader economic and political context of reform proposals as well as on their legal, institutional and procedural aspects. Therefore, the group asked external experts to produce a study on these topics. In addition, it identified a number of related questions that deserve further analysis, for example:

- whether previous proposals foundered as a result of their intrinsic features or because of procedural elements;

- whether significant modifications of the system will be impossible without changes in the decision-making mechanism;

- whether differentiated solutions for subgroups of Member States, for example through enhanced cooperation, could make reform happen;

- whether the traditional approach of linking the negotiations on own resources with those on the EU's multiannual expenditure plans under the MFF may represent a stumbling block or instead ease the way to an agreement on the revenue side of the 
budget;

- and whether the euro area is of relevance for the reform process.

Finalised in June 2016, the study commissioned on behalf of the HLG (Núñez Ferrer J. et al. 2016) tackles multiple aspects of a possible reform, including: its political and legal dimension; potential new resources; and improvements on the expenditure side of the budget. On this basis, the authors present a series of possible package deals for a reform, analysing their merits.

In addition, the work of the HLG has revived the debate on the financing system of the EU, with many contributions produced by academia and stakeholders. Examples include the working papers produced by two German universities (Buettner T. et al. 2016) in a research project for the German Federal Ministry of Finance. These papers explore the concept of European public goods and the meaning of the subsidiarity principle in the context of the EU budget, before analysing two possible new resources (European road transport fuel taxes and an electricity tax). The Dutch Presidency of the Council (in place for the first half of 2016) included the reform of the EU budget among its institutional priorities, putting strong emphasis on the link between the revenue and expenditure sides of the budget.

Based on all these contributions, the most promising options for a reform will be assessed by national parliaments at an inter-institutional conference to be hosted by the European Parliament in September 2016. The HLG will take the outcome of this debate into account for its final report, which it expects to present by mid-December 2016.

\section{Outlook.}

There is a widespread consensus among political stakeholders and researchers that the EU budget needs reform. This includes its revenue side which, some analysts say, should be the starting point, considering that a higher degree of EU financial autonomy could help to modify the structure of EU expenditure as well, aligning it more to the new challenges that the Union has to tackle. Even those who oppose more financial autonomy for the EU generally agree that the current financing system should be streamlined.

As Becker (2012) puts it, the need for reform does not necessarily translate into the 
ability to reform. A major obstacle to this end lies in the decision-making procedure that applies to the own resources system, which requires unanimity in the Council and ratification by all Member States. This makes veto threats extremely credible. Times of economic crisis may prove to be an additional obstacle to reforming the financing system.

However, experience shows that reforms and agreements are possible even if difficult. An overhaul of the system should not aim at marginal adjustments, since over time these have often proved to introduce new layers of complexity. A reform should rather be the opportunity for real simplification and streamlining.

The EP has very limited influence on the revenue side of the EU budget, but has long pushed for its overhaul. A July 2016 resolution (European Parliament 2016) strongly reaffirmed this; recalling the new and serious crises that the EU has been confronted with in recent years, the EP stressed that changes in both the MFF and the own resources system are needed if the EU is to address properly a number of challenges and to fulfil effectively its policy objectives. As regards own resources in particular, the EP is expecting an ambitious final report from the HLG this year and an equally ambitious reform proposal by the Commission in 2017, with an overhaul of the system as of 2021.

In July 2016, in an exchange of views with the EP's Committee on Budgets, the chair of the HLG Mario Monti said that recent crises have shown that the current EU budget is not fit for purpose. While the mandate of the HLG is only on the revenue side of the budget, the HLG will underline that improvements are also needed on the expenditure side. Monti noted that the way to reduce conflict over net contributions would be by focusing on the notion of European public goods that cannot be provided effectively at the national level, but which are crucial for the welfare and security of citizens. In addition, some related policy-driven resources could contribute to the achievement of policy objectives and give, at the same time, a clearer picture of what the EU does. Examples cited of possible European public goods were: internal and external security; financial stability and fight against tax avoidance (with related resources such as an FT'T or an FAT); economic growth and investments; and quality of the environment and fight against climate change (with related resources such as a carbon tax, ETS revenues or a share of national fuel taxes).

In line with this possible focus on European public goods, the data of a 2016 Eurobarometer survey appear to suggest that, in many policy areas, there is a gap between 
citizens' perception of current EU involvement and their expectations and preferences for future EU action. ${ }^{\text {xxxix }}$

To conclude, Commission documents and proposals, Parliament's resolutions and academic research have identified the main areas for consideration, which include:

- The possible introduction of new genuine own resource(s) in line with Treaty provisions. No potential candidate seems able to meet all the numerous assessment criteria that have been developed over time. However, some should allow the striking of a good balance (possibly with a mix of resources).

- Addressing the issue of correction mechanisms, which are widely recognised as a source of inequity and distortion in the system.

- Eliminating the current VAT resource, since it is extremely complex and does not appear to provide any real added value to the system.

In addition, some kind of link between a new own resource and specific objectives could help to increase the focus on the provision of collective goods with EU added value. For example, an EU energy tax could be coupled with cross-border investment in energy infrastructure. In 2014, manufacturers called for a coordinated EU energy policy, underlining the strategic importance that developing a European "smart grid" would have for the competitiveness of the entire European industrial sector. A new resource could be expected to gain support if it helps to address issues widely perceived as not being easily addressed at the national level, but necessitating joint action. With regard to this, some analyses (e.g. Tarschys 2015) draw attention to the emergence of footloose tax bases often linked to the digital economy, while others (e.g. Peeters 2015) focus on the challenges posed by corporate tax avoidance (the OECD conservatively estimated annual losses due to this issue between USD100 billion and USD240 billion in the framework of the BEPS project).

The objective of the final report of the HLG will be to devise viable recommendations to resolve the stalemate seen up to now, despite the rather broad consensus among stakeholders that the current financing system could be improved. Following the final report, the European Commission will examine whether the outcome of the work justifies new initiatives in the field of Own Resources, with possible reform of the financing of the EU budget for the period covered by the next MFF. 


\footnotetext{
* The content of this document is the sole responsibility of the author and constitutes a personal opinion.

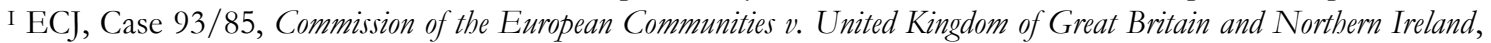
1986, ECR 4011.

II Council Decision (EU, EURATOM) 2014/335 on the system of own resources of the European Union (OJ L 168, 7.6.2014, p. 105). In June 2016, the ratification process was still ongoing since two Member States had not yet ratified the 2014 Decision.

III With some Member States granted exceptions for both the expenditure and the revenue side.

IV The European Parliament drew attention to the high number of exceptions in its resolution of 29 March

2007 on the future of the European Union's own resources (P6_TA (2007)0098).

$\mathrm{V}$ The EU Budget Review - COM (2010)700 - of 19 October 2010.

VI EP resolution of 25 November 2010 on the on-going negotiations on the 2011 budget (P7_TA (2010)0433).
}

VII See for example: EP resolution of 13 March 2013 on the general guidelines for the preparation of the 2014 budget - Section III - Commission (P7_TA (2013)0081).

VIII Amended proposal for a Council Decision on the system of own resources of the European Union COM (2011)739 - of 9 November 2011.

IX Proposal for a Council Directive implementing enhanced cooperation in the area of financial transaction tax - COM (2013)71 - of 14 February 2013.

x ECA's opinion No 2/2012.

XI EP resolution of 23 October 2012 in the interests of achieving a positive outcome of the Multiannual Financial Framework 2014-2020 approval procedure (P7_TA (2012)0360).

XII EP legislative resolution of 23 October 2012 on the proposal for a Council regulation on the methods and procedure for making available the own resource based on the value added tax (P7_TA (2012)0361).

XIII Conclusions of the European Council as regards the item Multiannual Financial Framework of 8 February 2013 (EUCO 37/13).

XIv EP legislative resolution of 16 April 2014 (P7 TA (2014)0431).

xV EP legislative resolutions of 16 April 2014 (P7 TA (2014)0432 and P7 TA (2014)0433).

XVI See for example a study financially supported by the German Federal Ministry of Finance: Heinemann et al. (2008). The authors suggest creating a generalised but limited correction mechanism, with a clear distinction between policies with redistributive objectives and those supporting the provision of European public goods.

$\mathrm{XVII}$ This topic is not tackled in this document, since providing the EU with the ability to borrow would require a Treaty change.

XVIII In the subsequent debate, the UK maintained its view that the EU budget continues to have distortions on the expenditure side and that, on this basis, the rebate remains consistent with the Fontainebleau principles.

XIx Presidency Issues Paper: Multiannual Financial Framework 2014-2020 of 30 August 2012.

xx ECA's opinion No 4/2005.

XxI The policy of economic and social cohesion was established by the Single European Act in 1986. The Lisbon Treaty has widened the concept to include territorial cohesion.

XXII In its 1999 report on the need to modify and reform the European Union's own resources system (A40105/99), the Budget Committee of the EP suggested further reducing the share of the EU budget devoted to agriculture by introducing $50 \%$ co-financing of this policy from national budgets. Parliament did not retain this idea in its resolution of 11 March 1999.

XxiII Also known as spill-over costs, these are external costs (e.g. pollution) suffered by third parties that receive no compensation.

XXIV Therefore, if one category of goods is not subject to the standard VAT rate in just one Member State, it is automatically excluded from the base in all Member States.

xxv As mentioned, the European Court of Auditors deems the proposal to bring some improvements in terms of simplification in comparison with the current system, while noting aspects of the text that need further clarifications.

xxvi In 2010, the Commission published a Green Paper on the future of VAT.

xxVII Attempts to reform EU VAT provisions in this direction have been so far unsuccessful.

XXVIII See for example: Leen 2012a. Nevertheless, the author notes that opinions differ on the desirability of 
meeting the visibility criterion, at least for governments.

xxIX ECJ, Case C-209/13, United Kingdom of Great Britain and Northern Ireland $v$ Council of the European Union, 2014.

xxx 3310 ${ }^{\text {th }}$ Council meeting (Economic and Financial Affairs) of 6 May 2014 (9273/14).

xxxi EU Financial Transactions Tax Could Face New Hurdle / Dendrinou V., in: The Wall Street Journal, 25 January 2016.

XXxII See for example: Europe still sets the standard for a low-carbon future / Sachs J., in: Financial Times, 28 January 2014.

XXXIII Greece, other EU strugglers emerge winners from carbon reforms-data / Twidale S., Lewis B., 7 May 2015.

xxxiv Proposal for a Council Directive amending Directive 2003/96/EC restructuring the Community framework for the taxation of energy products and electricity - COM (2011)169 - of 13 April 2011.

xxxv Energy prices and costs in Europe - COM (2014)21/2 -of 29 January 2014.

xxxvi OECD/G20 Base Erosion and Profit Shifting Project, 2014, Addressing the Tax Challenges of the Digital Economy.

XXXVII In terms of GNI per capita.

XXXVIII This may appear to contradict the rationale behind the 'Fontainebleau principles', which underpinned the creation of the UK rebate, the first correction mechanism. According to these principles, while 'expenditure policy is ultimately the essential means of resolving the question of budgetary imbalances', the contribution of a country should be considered in relation to its relative prosperity.

Xxxix For more details, see for example: Dobreva A. et al., 2016, Public expectations and EU policies: Identifying the gaps, European Parliamentary Research Service, Brussels.

\section{References}

- $\quad$ Becker Peter, 2012, Lost in Stagnation: The EU's Next Multiannual Financial Framework (2014-2020) and the Power of the Status Quo, Stiftung Wissenschaft und Politik, Berlin.

- $\quad$ Begg Iain et al., 2008, Financing of the European Union budget, Report to the European Commission.

- Benedetto Giacomo, 2013, 'The EU budget after Lisbon: rigidity and reduced spending?', Journal of Public Policy, XXXIII(3): 345-369.

- Benedetto Giacomo et al. (eds), 2012, European Union Budget Reform, Palgrave Macmillan, Basingstoke

- Buettner Thiess et al. (eds), 2016, The Future of EU-Finances, Working Papers for the Brussels Symposium on 14 January 2016, Research project for the Federal Ministry of Finance, Germany.

- D'Alfonso Alessandro, 2014a, Annual revision of national contributions to the EU budget, European Parliamentary Research Service, Brussels.

- D'Alfonso Alessandro, 2014b, How the EU budget is financed: The "own resources" system and the debate on its reform, European Parliamentary Research Service, Brussels.

- D'Alfonso Alessandro, 2015, 'Monti' Group's first assessment of EU own resources, European Parliamentary Research Service, Brussels.

- D'Alfonso Alessandro, 2016, The UK 'rebate' on the EU budget: An explanation of the abatement and other correction mechanisms, European Parliamentary Research Service, Brussels.

- De Feo Alfredo et al. (eds), 2016, EU Own Resources: Momentum for a Reform?, European University Institute, Florence.

- d'Oultremont Clémentine et al., 2013, Reforming the system of financing the EU budget, Egmont Royal Institute for International Relations, Brussels.

- $\quad$ Enderlein Henrik et al., 2012, Completing the euro - A road map towards fiscal union in Europe: Report of the "Tommaso Padoa-Schioppa Group', Notre Europe.

- $\quad$ European Commission, 1998, Financing the European Union - Report on the operation of the own resources system.

- European Commission, 2004, Financing the European Union - Report on the operation of the own resources system. 
- $\quad$ European Commission, 2010, The EU Budget Review.

- $\quad$ European Commission, 2011, Financing the EU budget - Report on the operation of the own resources system.

- $\quad$ European Commission, 2014, European Union Public Finance (Fifth edition), Publications Office of the European Union, Luxembourg.

- European Parliament, 1999, Resolution on the need to modify and reform the European Union's own resources system, OJ C 175, 21.6.1999.

(2007)0098.

- $\quad$ European Parliament, 2016, Preparation of the post-electoral revision of the MFF 2014-2020: Parliament's input ahead of the Commission's proposal, P8_TA (2016)0309.

- Haug Jutta et al., 2011, Europe for Growth: Towards a radical change in financing the EU, Centre for European Policy Studies (CEPS), Brussels.

- Heinemann Friedrich et al., 2008, Reform options for the EU own resources system, Physica-Verlag, Heidelberg.

- Houser Matthieu, 2011a, Le budget de l'Union européenne, Eska, Paris.

- Houser Matthieu, 2011b, Les fondements du budget de l'Union européenne, Eska, Paris.

- Kaiding Josephine, 2014, 'The Financial Transaction Tax: The Way Forward for the European Union?' EC tax review, XXIII(1): 30-42.

- Le Cacheux Jacques, 2005, European Budget : the poisonous budget rebate debate, Notre Europe.

- $\quad$ Leen Auke R., 2012a, 'An EU financial transaction tax: a three-fold assessment', in Fuxman Leonora et al. (eds), Mapping the Global Future: Evolution through Innovation and Excellence, GBATA, New York, 432-439.

- $\quad$ Leen Auke R., 2012b, Note on the budget of the European Union and an Internet Communication Tax, Policy Studies Organization.

- $\quad$ Leen Auke R., 2012c, 'Seigniorage: A True European Tax', EC tax review, XXI(6): 331-334.

- $\quad$ Leen Auke R., 2013, 'Een nieuw eigenmiddel van de EU: de wederopstanding van de BTW', Weekblad Fiscaal Recht, no. 7006: 783-788.

- $\quad$ Núñez Ferrer Jorge et al., 2016, Potential and Limitations of Reforming the Financing of the EU Budget, study commissioned by the European Commission on behalf of the High Level Group on Own Resources.

- $\quad$ Patterson Ben, 2011, Understanding the EU budget, Searching Finance, London.

- Peeters Bruno, 2015, 'EUCIT: For How Much longer will political objections outweigh the advantages?', EC Tax Review, XXIV( 3): 128-131.

- $\quad$ Sapir André et al., 2003, An Agenda for a Growing Europe: The Sapir Report, Oxford University Press, Oxford.

- Schratzenstaller Margit, 2013, 'The EU Own Resources System - Reform Needs and Options', Intereconomics, XLVIII(5): 303-313.

- Tarschys Daniel, 2015, 'Entering a world of footloose tax bases: can the EU generate its own income?', European Policy Analysis, issue 8. 